\title{
The Application of a Managerial Competency Model in Employee Promotion - Combination of AHP and VIKOR Methodology
}

\author{
HsienYu, Shun ${ }^{1} \&$ KuoYan, Wang ${ }^{2}$ \\ ${ }^{1}$ Department of Marketing, Guang Dong University of Petrochemical Technology, China \\ Correspondence: Department of Marketing, Guang Dong University of Petrochemical Technology, China. \\ E-mail: jerryhysun@hotmail.com
}

Received: May 1, 2020

Accepted: May 28, 2020

Online Published: June 8, 2020

doi:10.5539/ijbm.v15n7p77

URL: https://doi.org/10.5539/ijbm.v15n7p77

\begin{abstract}
Managerial competency model is a main structure that lists competencies needed for manager's position. This paper established a employee promotion application combined with managerial competency model and AHP-VIKOR methodology. Research was carried using qualitative and quantitative methods. The managerial competency model is explained through a literature review and internal interview is to confirm the specific competency items that suitable for case company. Research from expert panels is used to evaluate the managerial competency of the candidates in the case study. The quantitative tool was AHP and VIKOR model. AHP was applied to calculate the criteria weights of managerial competency items. VIKOR multi-criteria decision making model ranked the alternatives and the most suitable promotion candidate was selected. The results from the VIKOR model were used as the decision-making basis for the promotion of the best candidate. This research expected to use the quantitative method to support the executive management level to develop internal talent base on a objective evaluate results.
\end{abstract}

Keywords: AHP, competency, managerial competency model, Vikor

\section{Introduction}

Organizations need to cultivate high-performance managers for continuous development and to maintain competitive advantages (Wexley \& Baldwin, 1986). To effectively develop managerial competency, enterprises need to address the development requirements of managers at different levels. Through the competency evaluation process of individual managers, the organization can understand an individual's strengths and weaknesses and then improve managerial competency in a targeted way. Through internal organization development, companies may achieve better managerial competency development (McCall \& Lombardo, 1988). Managerial competency refers to necessary capacities, such as knowledge, skill, ability and personality (Luo, 2012). In order to structure a framework for the management level, a managerial competency model can direct the critical Human Resource Management process of recruitment, performance appraisal, training and development.

This research provides a viewpoint of how to use the decision making model to evaluate employee's competency and performance who are able to promote. This study is combined with the AHP and VIKOR methods. Riza and Irianti (2015) thought that the best way to do employee promotion is to use AHP-VIKOR method which is intended to analyze and determine preferences for a number of established criteria. AHP method with the VIKOR method is able to provide optimal results in ranking the selection process from five employees with seven criteria through the index system using the VIKOR method (Akmaludin et al., 2019).

\section{Literature Review}

\subsection{Competency and Managerial Competency}

In 1973, David McClelland wrote an article "Testing for Competence Rather than Intelligence". McClelland's research point out that although the traditional academic aptitude and knowledge test were good predictors of academic performance, but this measurement way was hard to predict the working performance. McClelland went on to argue that the best predictors of outstanding on-the-job performance were underlying, enduring personal characteristics that he called "competencies" (Vikram \& Sandeep, 2014). Competency can evaluate individual ability that relates to the performance of a specific position, and a competency model is the set of 
knowledge, skills, abilities that needed to reach excellent results (Königová Martina et al., 2012; Campion, Fink, Ruggeberg, Carr, Phillips, \& Odman. 2011; Hollenbeck et al., 2006; Marrelli et al., 2005; Lucia \& Lepsinger, 1999; McClelland, 1998; McClelland, 1973).

Senior managers are the top management level and policy-makers, who have decision-making authority over the management of a whole organization. They have the most intimate relationship with the external environment and need to take the final duties for the organization. Managerial competency refers to the competence for management tasks or the knowledge, skill, and ability required for the management of affairs (Luo, 2012). Lojda (2011) defined managerial competence as "capability of the staff to perform the job, the need to extent and expect quality of a specific position or activity." Wang \& Hong (2012) outlined that a senior executive manager focuses on improving performance, developing organizational talents, changing leadership when necessary, refining customer orientation, and improving decision-making ability.

Different studies have different viewpoints on the most important managerial competency skills. Wang (2013) used an expert panel methodology to develop the managerial competencies for a company and selected seven: performance management, cost control, leadership, decisiveness, talent development, creativity, communication, and negotiation. Lee and Kim (2018) point out that a leader's managerial skills include a variety of abilities, such as strategic vision, persuasive, administrative capability, and knowledge about group skills and social skills, all of these items have the influences for organizational performance. Nader, Sanaz, Sima and Milad (2018) suggest that managerial competency includes planning intelligence, strategic thinking, goal setting, coordination, delegating roles and functions, resource allocation, effective communication, team building, changes in management when necessary, conflict management, negotiation, management of organizational climate and culture, inspiration, trust and credibility, professionalism, commitment to the customer, self-management, performance evaluation, and feedback. There is no single best competency requirement for a company, with each company having specific competencies relative to its goals and needs.

\subsection{Managerial Competency Model}

A competency model is a framework that lists competencies required for effective performance in a specific job position, job family (a group of related jobs), organization, function, or process (Marelli, 2005). The ultimate goal of a competency model is a comprehensive assessment of knowledge, skill, ability, and characteristics that an individual must possess to achieve high-performance standards for a specific job. Since the seminal study of McClelland (1973), competency modeling has expanded broadly into a variety of fields and disciplines, including a leader's competency for creativity and innovation (Halbesleben, Novicevic, Harvey, \& Buckley 2003), project managers (Müller \& Turner, 2010) .Leadership competency modeling identifies the specific competencies required to enhance leadership effectiveness (Thach \& Thompson, 2007; Hollenbeck, McCall, \& Silzer 2006; Hood \& Lodge, 2004; Halbesleben et al., 2003). Krajcovicova (2012) argued that competency models could be developed for specific jobs, job groups, organizations, occupations, or industries.

Generally, the management level of an organization is divided into three managerial levels: first-line, mid-level, and senior-level (Mirabile, 1997). First-line manager responsibilities are to perform the work, improve the efficiency of the work, and complete the work objectives. Mid-level managers need to be responsible for communicating and coordinating with other levels so that the organization can become a streamlined working team. The senior-level manager has decision-making power for the operation and management of an entire organization. He or she has the most intimate relationship with the external environment and takes the responsibility of the entire organization (Wang \& Hong, 2012). Due to different responsibilities and job requirements, from the first-line to the senior level, necessary managerial competencies will different.

\section{Research Method}

This research method is combination of qualitative and quantitative method. Qualitative way we use the literature review and internal interview to develop the case company's senior-level managerial competency model. Quantitative way use AHP to calculate the criteria weights of managerial competencies. The VIKOR model is to rank the alternatives and the most suitable promotion candidate was selected. The evaluation and calculation process explain as below.

\subsection{Literature Review and Internal Interview}

The goal of literature review and interview is to establish the managerial competency model for the company's senior management level and identify key competency items. Researchers use the literature review to list the general managerial competency items and definition. The purpose of the internal interview is to collect internal opinions from the CEO and internal senior managers and identify the managerial competency items. This stage 
expects to identify what managerial competency is required (for director level and above) of case company.

\subsection{AHP Method}

The AHP (Analytic Hierarchy Process) proposed by Satty (1990) is how to derive relative scales using judgment or data from a standard scale, and how to perform the subsequent arithmetic operation on such scales avoiding useless number crunching.

The judgments are given in the form $\mathrm{CR}=\mathrm{CI} / \mathrm{RI}$ paired comparisons. Let $A$ represent an $[\mathrm{n} \times \mathrm{n}]$ comparison matrix as stated in (1). The values on the diagonal have equal relevance (1) due to the self-comparison. Then, normalize matrix A and obtain factor weights by applying (2). Wi is the importance degree for the $i_{\text {th }}$ factor.

$$
\begin{aligned}
A & =\left[\begin{array}{cccc}
1 & \mathrm{a}_{12} & \cdots & \mathrm{a}_{1 \mathrm{n}} \\
\mathrm{a}_{21} & 1 & \cdots & \mathrm{a}_{2 \mathrm{n}} \\
\vdots & \vdots & \ddots & \vdots \\
\mathrm{a}_{\mathrm{n} 1} & \mathrm{a}_{\mathrm{n} 2} & \cdots & 1
\end{array}\right] \\
\mathrm{W} i & =\frac{\left(\prod_{j=1}^{n} a_{i j}\right)^{1 / n}}{\sum_{i=1}^{n}\left(\prod_{j=1}^{n} a_{i j}\right)^{1 / n}} \quad, \mathrm{i}, \mathrm{j}=1,2,3 \ldots \ldots \mathrm{n}
\end{aligned}
$$

To ensure that criteria weights derived from the pairwise comparison matrix $A$ are acceptable, the consistency indexes must be calculated via applying (3) to (4). Here, $\lambda_{\max }$ is the maximum eigenvalue and $\mathrm{n}$ represents the matrix size. Besides, $\mathrm{CV}$ represents the consistency values for factors and is defined as $\mathrm{CV}=\left[\mathrm{cv}_{\mathrm{i}}\right]_{\mathrm{xn}}$ where $\mathrm{cv}_{\mathrm{i}}=$ $\mathrm{c}_{\mathrm{i}} / \mathrm{w}_{\mathrm{i}}(\mathrm{i}=1,2, \ldots, \mathrm{n})$.

$$
\begin{aligned}
& \lambda_{\max }=\frac{\sum_{i=1}^{\mathrm{n}} \mathrm{Cv}_{i}}{\mathrm{n}} \\
& \mathrm{CI}=\frac{\lambda_{\max }-n}{n-1}
\end{aligned}
$$

On the other hand, matrix $\mathrm{C}$ denotes an $\mathrm{n}$-dimensional column vector representing the total of the weighted values for the importance intensity of criteria as (5). Then, CR (Consistency Ratio) is computed via using (6) where RI denotes the random consistency index. In cases where the individual matrix turns out to be inconsistent, i.e. with $\mathrm{CR}>0.1$, we apply the consistency adjustment procedure.

$$
\begin{aligned}
& \mathrm{C}=\left[c_{i}\right]_{\mathrm{nxl}}, \mathrm{n}=1,2,3 \ldots \ldots \mathrm{n} \\
& \mathrm{CR}=\frac{\mathrm{CI}}{\mathrm{RI}}
\end{aligned}
$$

\subsection{The VIKOR Methodology}

VIKOR is a solution of ranking method, is the concept of compromise which deals with the competition between evaluation criteria (Opricovic, 1998). It belongs to the optimization compromise programming of multiple criteria decision making (MCDM). First step is to define the positive ideal solution and the negative ideal solution then rank the priority among the alternatives by comparing the evaluation value of each solution and the approach degree of the ideal solution. It is characterized by maximizing group benefits and minimizing individual regrets of objections. This research is used the VIKOR method in actual case and the calculate process is as below:

(1) Determine all the criterion functions, denoted as a positive ideal $A_{i}^{*}$ and the negative ideal $A_{i}^{-}$. $\mathrm{i}=1,2,3 \ldots . \mathrm{n}$

$$
A_{i}^{*}=\max _{j} A_{i j}, A_{i}^{-}=\min _{j} A_{i j} .
$$

(2) Calculate the values $\mathrm{Sj}$ and $\mathrm{Rj}$ for $\mathrm{j}=1,2,3, \ldots, \mathrm{J}$ :

$$
S_{j}=\sum_{i=0}^{n} w_{i}\left(f_{i}^{*}-f_{i j}\right) /\left(f_{i}^{*}-f_{i}^{-}\right), R_{j}=\max _{i}\left[w_{i}\left(f_{i}^{*}-f_{i j}\right) /\left(f_{i}^{*}-f_{i}^{-}\right)\right],
$$

Where $\mathrm{w}_{\mathrm{i}}$ are the weights of criteria, expressing the relative importance by the analytic hierarchy process (AHP). 
(3) Calculate the values $Q_{j}$ for $j=1,2,3, \ldots, J$ by the relation:

$$
Q_{j}=v\left(S_{j}-S^{*} / S^{-}-S^{*}\right)+(1-v)\left(R_{j}-R^{*}\right) /\left(R^{-}-R^{*}\right)
$$

Where

$$
\begin{aligned}
& S^{*}=\min _{j} S_{j}, \\
& =\min \left[\left(S_{j}\right)_{\mid} j=1,2,3, \ldots, n\right] \\
& S^{-}=\max _{j} S_{j}, \\
& =\max \left[\left(S_{j}\right)_{\mid} j=1,2,3, \ldots, n\right] \\
& R^{*}=\min _{j} R_{j}, \\
& =\min \left[\left(R_{j}\right)_{\mid} j=1,2,3, \ldots, n\right] \\
& R^{-}=\max _{j} R_{j}, \\
& =\max \left[\left(R_{j}\right)_{\mid} j=1,2,3, \ldots, n\right]
\end{aligned}
$$

and $\mathrm{v}$ is introduced as the weight of the strategy of the maximum group utility, according to the definition of Kackar (1985), Opricovic (1998), and Chang (2011) with $v=0.5$.

(4) Ranking the alternatives by $Q_{j}$. If the value of $Q_{j}$ is less, the alternative is the better solution. Once the calculation offers a maximum group utility and a minimum participant regret (or disappointment), the obtained compromise solution is the consent of the majority by decision-makers.

\section{Results and Discussion}

This project divided into two stages: the first stage is to carry out internal interviews and questionnaires. The second stage used internal and external expert panels to evaluate the promotion of candidates based on the managerial competency model.

The purpose of the questionnaire survey is to make a specific choice on the importance of managerial competencies based on the opinions of senior management and the CEO. The content of the questionnaire is based on the managerial competency from the literature review and the results of interviews with internal staff. According to the results, the questionnaire lists ten managerial competency items. The rating used Likert's five-level scale to measure opinions (Table 1).

Table 1. Managerial competency ranking by mean score

\begin{tabular}{llll}
\hline $\begin{array}{l}\text { Alternatives } \\
\text { ranking }\end{array}$ & Competency Items & Samples & Mean Score \\
\hline 1 & Strategic Thinking & 8 & 4.65 \\
2 & Communication \& Negotiation & 8 & 4.42 \\
3 & Leadership & 8 & 4.35 \\
4 & Planning \& Organization & 8 & 4.28 \\
5 & Engagement & 8 & 4.13 \\
6 & Project management & 8 & 4.06 \\
7 & Decision-Making & 8 & 3.98 \\
8 & Pressure Resistant & 8 & 3.92 \\
9 & Objective Orient & 8 & 3.86 \\
10 & Analytical skill & 8 & 3.73 \\
\hline
\end{tabular}


In the second stage, five decision participants discussed and evaluated the managerial competencies of the promotion candidates: two members from the management committee of case company, one CEO from an industry association, one business academic, and a management consultant (Table 2).

Table 2. Expert fields

\begin{tabular}{ll}
\hline Experts & Field \\
\hline Case company Chief Operating Officer & Internal \\
Case company Chief Human Resource Officer & Internal \\
Industry association expert & Industry \\
Management consultant & Industry \\
Business school professor & Academic \\
\hline
\end{tabular}

Using the expert panel, one appropriate mid-level manager was promoted to Chief Operating Officer (COO) of case company. Five mid-level managers in case company were chosen as candidates. According to their experience and comprehensive competence and performance, these managers are in the succession echelon of senior management in case company. Once criteria were identified, the five professional experts assessed candidates using the AHP. Table 3 illustrates the weight of each competency item.

Table 3. Each dimensions and criteria AHP weights

\begin{tabular}{|c|c|c|}
\hline Item & Strategic Criteria for Consideration & Average \\
\hline 1 & Strategic Thinking & 0.1137 \\
\hline 2 & Communication \& Negotiation & 0.1086 \\
\hline 3 & Leadership & 0.1178 \\
\hline 4 & Planning \& Organization & 0.0251 \\
\hline 5 & Engagement & 0.0613 \\
\hline 6 & Project management & 0.0949 \\
\hline 7 & Decision-Making & 0.1812 \\
\hline 8 & Pressure Resistant & 0.0768 \\
\hline 9 & Objective Orient & 0.1711 \\
\hline 10 & Analytical skill & 0.0495 \\
\hline
\end{tabular}

Table 4 illustrates the rating of each candidate's working performance by the experts (from $1=$ extremely unsatisfied to $9=$ extremely satisfied). Table 5 shows the weighted normalized decision matrix used by steps 1-3.

Table 4. Raw Data of Each Candidate's Performance Scores

\begin{tabular}{|c|c|c|c|c|c|}
\hline \multirow{2}{*}{$\begin{array}{l}\text { Candidates } \\
\text { Criteria }\end{array}$} & \multicolumn{5}{|c|}{ Observation Candidate's Performance Scores } \\
\hline & $\mathrm{A}$ & $\mathrm{B}$ & $\mathrm{C}$ & $\mathrm{D}$ & $\mathrm{E}$ \\
\hline Strategic Thinking & 1 & 3 & 4 & 7 & 8 \\
\hline Communication \& Negotiation & 3 & 1 & 6 & 3 & 1 \\
\hline Leadership & 4 & 4 & 3 & 1 & 5 \\
\hline Planning \& Organization & 5 & 5 & 2 & 6 & 4 \\
\hline Engagement & 7 & 2 & 7 & 3 & 9 \\
\hline Project management & 8 & 5 & 1 & 5 & 2 \\
\hline Decision-Making & 2 & 3 & 6 & 2 & 4 \\
\hline Pressure Resistant & 7 & 6 & 8 & 9 & 2 \\
\hline Objective Orient & 2 & 4 & 5 & 1 & 3 \\
\hline Analytical skill & 4 & 5 & 7 & 4 & 6 \\
\hline
\end{tabular}


Table 5. Normalized Matrix with AHP weights

\begin{tabular}{|c|c|c|c|c|c|}
\hline $\begin{array}{l}\text { Candidates } \\
\text { Criteria }\end{array}$ & A & B & $\mathrm{C}$ & $\mathrm{D}$ & $\mathrm{E}$ \\
\hline Strategic Thinking & 0.1137 & 0.0812 & 0.0650 & 0.0162 & 0.0000 \\
\hline Communication \& Negotiation & 0.0652 & 0.1086 & 0.0000 & 0.0652 & 0.1086 \\
\hline Leadership & 0.0295 & 0.0295 & 0.0589 & 0.1178 & 0.0000 \\
\hline Planning \& Organization & 0.0063 & 0.0063 & 0.0251 & 0.0000 & 0.0126 \\
\hline Engagement & 0.0175 & 0.0613 & 0.0175 & 0.0525 & 0.0000 \\
\hline Project management & 0.0000 & 0.0407 & 0.0949 & 0.0407 & 0.0813 \\
\hline Decision-Making & 0.1812 & 0.1359 & 0.0000 & 0.1812 & 0.0906 \\
\hline Pressure Resistant & 0.0219 & 0.0329 & 0.0110 & 0.0000 & 0.0768 \\
\hline Objective Orient & 0.1283 & 0.0428 & 0.0000 & 0.1711 & 0.0856 \\
\hline Analytical skill & 0.0495 & 0.0330 & 0.0000 & 0.0495 & 0.0165 \\
\hline
\end{tabular}

For determining the ideal solution, we employed step 3 of the VIKOR calculation process to calculate the separation of each alternative solution from the ideal solution, which is demonstrated in Table 6 .

Table 6. VIKOR ranking results

\begin{tabular}{llllll}
\hline Candidates A & B & C & D & E \\
\hline Qj & 0.5121 & 0.0000 & 0.2799 & 0.6105 & 0.3666 \\
Ranking & 4 & 1 & 2 & 5 & 3 \\
\hline
\end{tabular}

The obtained VIKOR ranking lists by step 4 are presented in Table 6, indicating that Manager B should be considered as the appropriate person for the next COO. Manager D was questioned regarding his managerial competencies.

\section{Conclusion}

In this research, we try to combine technique for results obtained through the collaboration with AHP and VIKOR methods. Combination of the two quantitative methods may able to provide optimal solution when the selection processes from five promote candidates with all the competency criteria through the index system using the VIKOR method. Employee promotion can be determined according to the results obtained sequentially from the rank that can provide the decision makers have the specific information to select the appropriated candidate. This study makes the following recommendations:

First, there are differences between the priority importance of attitude recognition and the priority of the candidate's managerial competency importance. From the internal questionnaire survey result (Table 1), the ranking importance of the top three managerial items was strategic thinking (mean score: 4.65), communication and negotiation (4.42), and leadership (4.35). But, the AHP weighting result shows that decision-making (AVG: 0.18 ) is the most important criteria in evaluating the current manager requirement. This can be explained based on a candidate's psychological qualities that help determine a firm's key tasks and meet the responsibility level required. The next important criterion is object orientation (AVG: 0.17) and the third is leadership (AVG: 0.12). The research results not only can be used as an important priority adjustment for the competency of senior-level managers in the enterprise, but also as a decision-making basis for the priority of managerial competency development.

Second, these research results show that most of the managerial competency items seem related to emotional quality, e.g., for decision-making ability, a senior manager needs to make decisions quickly and definitively. An indecisive decision-maker may not be able to adapt to a competitive business environment. Also, he or she must be goal-oriented to meet the firm's tasks that demand a teamwork spirit. A competent senior-level manager also must show the ability to satisfy an organization's internal and external stakeholders. The VIKOR algorithm is an effective time and cost-saving tool for helping the enterprise choose the right person.

Third, the quantitative model is a benefit for decision-makers to analyze, judge, and compare results, and can effectively improve overall decision-making. As for the management practices mentioned, managers cannot decide without specific numbers. From this research, all the evaluation factors were significant, indicating that the senior management position is related to different criteria of work success. The VIKOR method acts to adjust 
the modeling hierarchy arranged structurally in comparison to the AHP, thus AHP can be said to be a decision solution with a rating system (Bakshi et al., 2016). The VIKOR model with AHP provides the specific numbers to illustrate what reasonable expectations for top-level managers should be.

Finally, the VIKOR model allows for directions for future research including succession programs, recruit talent decision making, and Management Associated assessment. It is reasonable to assume that the results of the quantitative decision model provide more meaningful and transparent information for a given company.

\section{References}

Akmaludin A., Astriana M., Budi, S., \& Kudiantoro, W. (2019). Position Based Job Promotion Using Multi-Criteria Elimination VIKOR Method. Journal of Physics: Conference Series, 1-8. https://doi.org/10.1088/1742-6596/1179/1/012013

Bakshi, T., Sinharay, A., Sarkar, B., \& Sanyal, S. (2016). MCDM Based Project Selection by F-AHP \& VIKOR.

Campion, M. A., Fink, A. A., Ruggeberg, B. J., Carr, L., Phillips, G. M., \& Odman, R. B. (2011). Doing competencies well: Best practices in competency modeling. Personnel Psychology, 64(1), 225-262. https://doi.org/10.1111/j.1744-6570.2010.01207.x

Chai-Fang, L. (2012). Building the competency model for high-tech company-G Company as an example. Master Degree Dissertation, National Taipei University.

Chang, C. L., \& Hsu, C. H.(2011). Applying a Modified VIKOR Method to Classify Land Subdivisions According to Watershed Vulnerability. Water Resource Manage, 25, 301-309. https://doi.org/10.1007/s11269-010-9700-2

Häder, M., \& Häder, S. (1995). Delphi und Kognitionspsychologie: Ein Zugang zur theoretischen Fundierung der Delphi-Methode. ZUMA-Nachrichten.

Halbesleben, J. R., Novicevic, M. M., Harvey, M. G., \& Buckley, M. R. (2003). Awareness of temporal complexity in leadership of creativity and innovation: A competency-based model. The Leadership Quarterly, 14(4), 433-454. https://doi.org/10.1016/S1048-9843(03)00046-8

Hollenbeck, G. P., McCall, M. W., \& Silzer, R. F. (2006). Leadership competency models. The Leadership Quarterly, 17(4), 398-413. https://doi.org/10.1016/j.leaqua.2006.04.003

Königová, M., Urbancová, H., \& Fejfar, J. (2012). Identification of Managerial Competencies in Knowledge-based Organizations. Journal of Competitiveness, 4(1), 129-142. https://doi.org/10.7441/joc.2012.01.10

Krajcovicova, K., Caganova, D., \& Cambal, M. (2012). Key Managerial Competencies and Competency Models in Industrial Enterprise. Annals of DAAAM for 2012 \& Proceedings of the 23rd International DAAAM Symposium, 23(1), 1119-1122.

Krakac, N. R. (1985). Off-line Quality Control, Parameter Design and the Taguchi Method. Journal of Quality Technology, 17(4), 176-188. https://doi.org/10.1080/00224065.1985.11978964

Kyoung-Joo, L., \& Eun-Young, K. (2018). A leadership competency model of science and technology parks: the case of Chungbuk Techno Park in Korea. Journal of Technology Management and Innovation, 13(4), 105-114. https://doi.org/10.4067/S0718-27242018000400105

Lojda, J., (2011). Manažérske dovednosti. Grada Publishing.

Lucia, A. D., \& Lepsinger, R. (1999). Art \& Science of Competency Models. San Francisco, CA: Jossey-Bass.

McCall, M. W., Lombardo, M. M., \& Morrison, A. M. (1988). The Lessons of Experience: How Successful Executives Develop on the Job. Lexington, MA: Lexington Book.

McClelland, D. C. (1973). Testing for competence rather than for intelligence. American Psychologist, 28(1), 1-14. https://doi.org/10.1037/h0034092

McClelland, D. C. (1998). Identifying competencies with behavioral event interviews. Psychological Science, 9(5), 331-339. https://doi.org/10.1111/1467-9280.00065

Mirabile, J. R. (1997). Everything You Wanted To Know About Competency Modeling. Training \& Development, 51(8), 73-77.

Müller, R., \& Turner, R. (2010). Leadership competency profiles of successful project managers. International Journal of Project Management, 28(5), 437-448. https://doi.org/10.1016/j.ijproman.2009.09.003 
Nader, M. M., Sanaz, Z. B. J., Sima, R., Ali, A. S., Ashraf, G., \& Milad, S. (2018). Managerial competencies of head nurses: a model and assessment tool. British Journal of Nursing, 27(21), 2-9.

Opricovic, S. (1998). Multicriteria Optimization of Civil Engineering Systems. Faculty of Civil Engineer. Belgrade. Practice: enterprise human resource system construction technology, examples and tools. Beijing: People's post and Telecommunications Press.

Riza, B. S., \& Irianti, J. (2015). Sistem Promosi Jabatan Dengan Menggunakan Analytic Network Process (Studi Kasus di PT . Maxi Media ). Konf. Nas. Sist. Inform, 789-794.

Saaty, T. L. (1990). Decision making for leaders: the analytic hierarchy process for decision making in a complex world. RWS publications.

Spencer, L., \& Spencer, M. (1993). Competence at work: model for superior performance. New York: John Wily \& Sons, Inc.

Vikram, S. C., \& Sandeep, S. (2014). Understanding the Competencies and Competency Modeling-A Literature Survey. Journal of Business Management, 16(1), 14-22. https://doi.org/10.9790/487X-16111422

Wang, S. J., \& Hong, Y. J. (2012). The Research of Competency Model-A Hospital Management Level. Journal of Technology Engineering and Education, 9(1), 70-82.

Wang, L. (2013). Relationship between Leadership Style and Development Managerial Competency---Case Study of a Taiwanese Cross-border Enterprise. EMBA Program, School of Business, SooChow University.

Wexley, K. N., \& Baldwin, T. T. (1986). Management Development. Journal of Management, 12(2), $274-294$. https://doi.org/10.1177/014920638601200209

\section{Copyrights}

Copyright for this article is retained by the author(s), with first publication rights granted to the journal.

This is an open-access article distributed under the terms and conditions of the Creative Commons Attribution license (http://creativecommons.org/licenses/by/4.0/). 